\title{
ANALISIS FAKTOR YANG MEMPENGARUHI PENERAPAN STANDAR AKUNTANSI KEUANGAN ENTITAS TANPA AKUNTABILITAS PUBLIK (SAK ETAP) PADA USAHA MIKRO KECIL DAN MENENGAH (UMKM)
}

\begin{abstract}
SAK ETAP is a one DSAK efforts to facilitate SMEs in preparing financial statements and to resolve its internal problem. SAK ETAP made not as complete as GAAP. However, until now the application of IFRSs ETAP is still very low. SAK ETAP still burdensome SMEs, the cause of SMEs still do not know the importance of making financial reports, the lack of knowledge of the owner of the accounting, and etc. So the purpose of this study is to analyze the factors that affect the implementation of ETAP SAK on SMEs. This study used a sample of 64 SMEs spread Area Tegal. The variables of this research is the application of IFRSs ETAP as the dependent variable, while the owner of education, understanding of Information Technology, the qualitative characteristics of financial statements and the size of the business as an independent variable. Data were analyzed using linear regression technique. The results of this study identify that education owner, understanding of Information Technology, the qualitative characteristics of financial statements and the size of the business and significant positive effect on the implementation of ETAP SAK on SMEs. This means that the higher education owner, understanding of Information Technology, the qualitative characteristics of financial statement report and the size of the business, the better the application of IFRSS ETAP.
\end{abstract}

Key words : qualitative characteristics of financial statemen, education owner, the implementation of ETAP SAK, the understanding of information technology, the size of the business

\section{PENDAHULUAN}

Usaha Mikro Kecil dan Menengah (UMKM) merupakan benteng dalam perekonomian Indonesia. Khususnya keterkaitan antara perkembangan UMKM dengan perekonomian di Indonesia, data yang dilansir dari Kementerian Negara Koperasi dan UMKM menunjukkan bahwa selama tahun 2006 - 2010 diprediksi telah terjadi peningkatan sumbangsih UMKM terhadap PDB Nasional (baik atas dasar harga berlaku maupun atas dasar harga konstan 2000), Total ekspor non migas nasional dan Investasi nasional (baik atas dasar harga berlaku maupun atas dasar harga konstan 2000). Dengan penguasaan pangsa pasar UMKM sebesar $57.12 \%$ pada tahun 2010, jika dibandingan dengan tahun 2006 maka pada tahun 2010 telah terjadi peningkatan kontribusi UMKM terhadap PDB atas dasar harga berlaku sebesar 94.37\%, begitupula berdasarkan PDB atas dasar harga konstan 2000, peningkatannya pada tahun 2010 dibandingkan tahun 2006 telah mencapai 23.85\%.

Sedangkan berdasarkan data total ekspor non migas nasional, sumbangsih UMKM pada tahun 2010 mencapai $15.81 \%$ atau naik 42.12 dari tahun 2006. Selain itu, berdasarkan data investasi nasional, dengan pangsa pasar yang masih sekitar $48.20 \%$ dibandingkan total investasi nasional pada tahun 2010, kenaikan investasi atas dasar harga berlaku pada sektor UMKM dibandingkan tahun 2006 mencapai 150.61\%. Sedangkan 
jika berdasarkan investasi atas dasar harga konstan 2000 maka tercatat bahwa peningkatan investasi UMKM pada tahun 2010 telah mencapai 360.2\% dibandingkan pada tahun 2006 silam Ferli (2013).

Berdasarkan data-data tersebut maka disimpulkan bahwa jumlah UMKM di Indonesia setiap tahunnya mengalami peningkatan yang signifikan, hal ini juga berdampak pada semakin meningkatnya kontribusi UMKM terhadap perekonomian Indonesia. Peningkatan tersebut tidak jauh dari peran faktor internal dari setiap UMKM. Faktor internal yang mempengaruhi adalah penyusunan laporan keuangan. Laporan keuangan merupakan komponen vital untuk memperoleh informasi mengenai posisi keuangan perusahaan dan hasil usaha yang dicapai oleh suatu perusahaan yang dilaporkan setiap akhir periode sebagai laporan pertanggungjawaban suatu perusahaan. Sedangkan mayoritas pengusaha UMKM tidak mampu memberikan informasi akuntansi terkait kondisi usahanya sehingga membuat informasi tersebut menjadi lebih mahal bagi perbankan Baas dan Schrooten (2006) seperti dikutip Rudiantoro dan Siregar (2011).

Namun, Praktek akuntansi pada UMKM di Indonesia masih rendah dan memiliki banyak kelemahan Suhairi (2004) seperti dikutip Wahdini dan Suhairi (2006); Raharjo dan Ali (1993) seperti dikutip Auliyah (2012); Benjamin (1990) dan Muntoro (1990) seperti dikutip Wahdini dan Suhairi (2006). Penelitian yang dilakukan oleh Benjamin (1990) seperti dikutip Wahdini dan Suhairi (2006) menyimpulkan bahwa rendahnya penggunaan dan pemahaman praktek akuntansi tersebut di Indonesia disebabkan rendahnya pendidikan dan kurangnya pemahaman terhadap Standar Akuntansi Keuangan (SAK) dari manajer pemilik (owner manager). Sedangkan Muntoro (1990) seperti dikutip Wahdini dan Suhairi (2006) menyimpulkan bahwa kelemahan tersebut disebabkan tidak adanya peraturan yang mewajibkan penyusunan laporan keuangan bagi UMKM. Keterbatasan pengetahuan pembukuan akuntansi, rumitnya proses akuntansi, dan anggapan bahwa laporan keuangan bukanlah hal yang penting bagi UMKM menurut Said (2009) seperti dikutip Rudiantoro dan Siregar (2011) membuat proses pembukuan laporan keuangan terhambat.

Melihat kejadian tersebut, Dewan Standar Akuntansi (DSAK) mengesahkah Standar Akuntansi untuk Entitas Tanpa Akuntabilitas Publik (SAK ETAP) pada 19 Mei 2009. Dengan adanya SAK ETAP diharapkan mampu memberikan kemudahan pada UMKM dalam menyusun laporan keuangannya dan dalam menyelesaikan masalah internal perusahaannya. SAKETAP memberikan banyak kemudahan untuk suatu entitas dibandingkan dengan SAK Umum dengan ketentuan pelaporan yang lebih kompleks Hariadi (2010) seperti dikutip Auliyah (2012). SAK ETAP ditujukan untuk entitas tanpa akuntanbilitas publik yaitu entitas yang tidak memiliki akuntanbilitas publik yang signifikan dan entitas yang menerbitkan laporan keuangan usahanya untuk keperluan kegiatan eksternal usahanya. SAK ETAP akan berlaku mulai 1 Januari 2011 apabila penerapannya sebelum tanggal efektif diperbolehkan.

SAK ETAP merupakan salah satu Standar Akuntansi yang penggunaanya ditujukan untuk entitas usaha yang tidak memiliki akuntabilitas publik, seperti entitas usaha kecil mikro dan menengah (UMKM). Secara umum SAK ETAP ini lebih mudah dipahami dan tidak sekompleks SAK Umum Rudiantoro dan Siregar (2011). Walaupun cukup ringkas, tidak banyak merubah prinsip-prinsip yang umumnya telah dilaksanakan saat ini. Kehadiran standar ini dapat menjadi acuan yang lebih mudah bagi kalangan yang lebih luas untuk penyusunan laporan keuangan yang dapat diterima secara umum Sariningtyas dan Diah (2011). 
Namun hingga saat ini penerapan SAK ETAP masih sangat rendah. SAK ETAP juga masih banyak dianggap memberatkan Usaha kecil dan Menengah Sariningtyas dan Diah (2011). Penyebabnya karena pengusaha kecil tidak memiliki pengetahuan akuntansi yang memadai, dan belum mengetahui pentingnya menyusun laporan keuangan bagi kelangsungan usahanya. Banyak pengusaha kecil yang mengganggap pelaporan keuangan tidaklah penting sehingga mereka mengabaikan cara pengungkapan laporan keuangan usaha mereka dan apabila dilaksanakan tidak disiplin setiap bulan dalam penyampainnya. Walaupun terlihat sangat sepele namun hal ini dapat menjadi masalah yang besar dalam perkembangan UMKM di Indonesia.

Penelitian yang dilakukan Sariningtyas dan Diah (2011), yaitu dugaan adanya pengaruh positif antara tingkat pendidikan pemilik, pemahaman teknologi informasi serta karakteristik kualitatif laporan keuangan terhadap kebutuhan SAK ETAP bagi UMKM. Dalam penelitian tersebut variabel pemahaman tehnologi informasi berpengaruh terhadap kebutuhan Standar Akuntansi Keuangan Entitas Tanpa Akuntabilitas Publik ( SAK ETAP) bagi Usaha Mikro Kecil dan Menengah ( UMKM ), sedangakan variabel tingkat pendidikan pemilik dan karakteristik kualitatif laporan keuangan tidak berpengaruh terhadap kebutuhan kebutuhan Standar Akuntansi Keuangan Entitas Tanpa Akuntabilitas Publik ( SAK ETAP) bagi Usaha Mikro Kecil dan Menengah ( UMKM ).

Penelitian lain yang mempunyai pengaruh terhadap penerapan SAK ETAP pada UMKM yaitu ukuran usaha seperti yang diteliti oleh Rudiantoro dan Siregar (2011). Pinasti (2001) seperti dikutip Rudiantoro dan Siregar (2011) menemukan bahwa ukuran usaha merupakan faktor yang sulit dipisahkan dengan lingkungan pengusaha UMKM. Ukuran usaha dapat mempengaruhi pemikiran pengusaha terkait dengan kompleksitas dan semakin tingginya tingkat transaksi perusahaan sehingga diharapkan dengan makin besarnya ukuran usaha maka dapat mendorong sesorang untuk berpikir dan belajar terkait solusi untuk menghadapinya. Hasil penelitian Rudiantoro dan Siregar (2011) menunjukkan bahwa ukuran usaha berpengaruh positif terhadap Persepsi Pengusaha UMKM atas pentingnya pembukuan dan pelaporan keuangan bagi usahanya, sehingga di saat semakin tumbuh dan besarnya usaha UMKM, maka pengusaha mulai memandang penting kebutuhan laporan keuangan tersebut.

Dilihat dari uraian diatas timbul pertanyaan faktor apa saja yang dapt mempengaruhi penerapan SAK ETAP pada UMKM. Peneliti tertarik untuk melakukan penelitian mengenai analisis faktor yang mempengaruhi penerapan SAK ETAP pada UMKM. Penelitian ini muncul karena beberapa permasalahan yang telah dijelaskan diatas dan hasil penelitian terdahulu yang menjelaskan bahwa SAK ETAP masih sulit diterapkan pada laporan keuangan UMKM.

\section{KERANGKA TEORITIS DAN PENGEMBANGAN HIPOTESIS}

\section{Kerangka Pemikiran Teoritis}

Kerangka pemikiran ini disusun khusus untuk menyusun analisis verifikatif yang nantinya akan diuji untuk menentukan kesimpulan tentang analisis faktor yang mempengaruhi penerapan Standar Akuntansi Keuangan Entitas Tanpa Akuntanbilitas Publik (SAK ETAP) pada Usaha Mikro Kecil dan Menengah (UMKM). Terdapat empat variabel yang ada pada penelitian ini. Empat variabel independen tersebut meliputi pendidikan pemilik 
(X1), pemahaman Tekhnologi Informasi (X2), Karakteristik Kualitatif Laporan Keuangan (X3), ukuran usaha (X4). Sedangkan variabel dependennya adalah penerapan SAK ETAP pada UMKM. Untuk lebih jelasnya dapat dilihat pada Gambar 1.

\section{Hubungan Pendidikan Pemilik terhadap Penerapan SAK ETAP pada UMKM}

Kemampuan dan keahlian manajer atau pemilik perusahaan mikro kecil dan menengah ditentukan dari pendidikan formal yang pernah ditempuh. Pemilik atau manajer perusahaan kecil dan menengah sangat dominan dalam menjalankan

perusahaan. Tingkatan pendidikan formal pemilik atau manajer perusahaan mikro kecil dan menengah sangat mempengaruhi kebutuhan informasi akuntansi keuangan dan manajemen Murniati (2002) seperti dikutip Sariningtyas dan Diah (2011).

Menurut Abrory (2004) seperti dikutip Sariningtyas dan Diah (2011) pendidikan manajer atau pemilik perusahaan akan diukur berdasarkan pendidikan formal yang pernah diikuti sehingga pengukurannya bersifat kontinyu. Pendidikan formal yang dimaksud adalah pendidikan yang diperoleh dibangku sekolah formal antara lain Sekolah Dasar (SD), Sekolah Menengah Pertama (SMP), Sekolah Mengengah Atas (SMA), Diploma, Sarjana dan Pascasarjana.

Tingkat pendidikan formal rendah (tingkat pendidikan sekolah dasar sampai dengan sekolah menengah umum) pemilik atau manajer akan rendah penyiapan dan penggunaan informasi akuntansi dibandingkan dengan tingkatan pendidikan formal yang tinggi (perguruan tinggi) pemilik atau manajer Abrory (2010) seperti dikutip Sariningtyas dan Diah (2011). Ini mungkin disebabkan karena materi pengajaran akuntansi lebih tinggi diberikan diperguruan tinggi dibandingkan dengan pendidikan yang lebih rendah. Menurut Sariningtyas dan Diah (2011) pendidikan pemilik diduga berpengaruh positif terhadap kebutuhan Standar Akuntansi Keuangan Entitas Tanpa Akuntabilitas Publik (SAK ETAP) bagi Usaha Mikro Kecil dan Menengah (UMKM).

Berdasarkan penjelasan di atas, maka hipotesis yang dapat diajukan adalah:

\section{H1 : Pendidikan pemilik berpengaruh positif terhadap penerapan SAK ETAP pada UMKM.}

Hubungan Pemahaman Teknologi Informasi terhadap Penerapan SAK ETAP pada UMKM

Pemahaman individu pada dasarnya merupakan pemahaman seluruh kepribadiannya dengan segala latar belakang dan interaksinya dengan lingkungannya Sariningtyas dan Diah (2011). Pemahaman pentingnya teknologi informasi bertujuan untuk mengadopsi dan memanfaatkan suatu informasi akuntansi, sebab informasi akuntansi digunakan sebagai pedoman dalam pengambilan keputusan, mencapai efisiensi dan efektifitas kegiatan usaha. Semakin paham terhadap teknologi informasi maka akan semakin luas pandangan mereka terhadap berbagai bentuk penerapan teknologi di dalam kehidupan bisnis dan akan dapat mendorong percepatan penyediaan informasi akuntansi yaitu berupa laporan keuangan bagi kalangan Usaha Mikro Kecil dan Menengah, maka peningkatan ketrampilan dan pemahaman terhadap teknologi informasi terutama pada para petinggi di dalam suatu perusahaan menjadi prasyaratan inti dalam mencapai efisiensi dan efektivitas kegiatan usaha Sariningtyas dan Diah (2011). Menurut Sariningtyas dan Diah (2011) pemahaman teknologi 
informasi diduga berpengaruh positif terhadap kebutuhan Standar Akuntansi Keuangan Entitas Tanpa Akuntabilitas Publik (SAK ETAP) bagi Usaha Mikro Kecil dan Menengah (UMKM).

Berdasarkan penjelasan di atas, maka hipotesis yang dapat diajukan adalah:

H2 : Pemahaman teknologi informasi berpengaruh positif terhadap penerapan SAK ETAP pada UMKM

\section{Hubungan Karakteristik Kualitatif laporan Keuangan terhadap Penerapan SAK ETAP pada UMKM}

Dalam menyusun laporan keuangan harus memenuhi karakteristik kualitatif laporan keuangan, dimana sebuah laporan keuangan baik itu perusahaan besar maupun yang kecil harus memenuhi karakteristik kualitatif laporan keuangan. Dalam Standar Akuntansi Keuangan Entitas Tanpa Akuntabilitas Publik disebutkan bahwa suatu laporan keuangan haruslah dapat dipahami, relevan, materialitas, keandalan, substansi mengungguli bentuk, pertimbangan sehat, kelengkapan, dapat dibandingkan, tepat waktu, keseimbangan biaya dan manfaat. Dengan memenuhi karakteristik yang diatur dalam SAK ETAP diharapkan dapat menyediakan informasi yang menyangkut posisi keuangan suatu

Usaha Mikro Kecil dan Menengah (UMKM) Sariningtyas dan Diah (2011). Menurut Sariningtyas dan Diah (2011) karakteristik kualitatif laporan keuangan diduga berpengaruh positif terhadap kebutuhan Standar Akuntansi Keuangan Entitas Tanpa Akuntabilitas Publik (SAK ETAP) bagi Usaha Mikro Kecil dan Menengah (UMKM).

Berdasarkan penjelasan di atas, maka hipotesis yang dapat diajukan adalah:

\section{H3 : Karakteristik kualitatif laporan keuangan berpengaruh positif terhadap penerapan SAK ETAP pada UMKM}

\section{Hubungan Ukuran Usaha terhadap Penerapan SAK ETAP pada UMKM}

Ukuran usaha dapat mempengaruhi pemikiran pengusaha terkait dengan kompleksitas dan semakin tingginya tingkat transaksi perusahaan sehingga diharapkan dengan makin besarnya ukuran usaha maka dapat mendorong sesorang untuk berpikir dan belajar terkait solusi untuk menghadapinya. Semakin besar usaha maka pemiliknya mulai memikirkan pentingnya suatu pembukuan dan pelaporan keuangan untuk membantu dalam pengelolaan aset dan penilaian kinerja keuangannya. Standar Akuntansi Keuangan Entitas Tanpa Akuntabilitas Publik (SAK ETAP) merupakan salah satu Standar Akuntansi yang penggunaanya ditujukan untuk entitas usaha yang tidak memiliki akuntabilitas publik, seperti entitas Usaha Mikro Kecil dan Menengah (UMKM). Hasil dari penelitian Rudianto dan Siregar (2011) yang dilakukan di daerah Depok dan Jakarta yaitu sebagian UMKM belum melakukan pembukuan akuntansi dan penyusunan laporan keuangan meskipun dalam bentuk yang sangat sederhana sekalipun karena usaha mereka yang masih sangat kecil ini belum membutuhkan hal tersebut dan mereka masih dapat mengandalkan ingatan mereka dalam mengelola keuangannya.

Hal ini menunjukkan bahwa SAK ETAP masih belum tersalurkan dengan baik kepada para pengusaha UMKM. Terkait dengan hal itu ukuran Usaha perlu diperhatikan. Maka pemahaman mereka terkait SAK ETAP akan menjadi lebih baik dan mendukung kesadaran mereka akan perlunya SAK ETAP bagi kelangsungan 


\section{JURNAL AKUNTANSI INDONESIA}

usahanya. Menurut Rudiantoro dan Siregar (2011) ukuran usaha diduga berpengaruh positif terhadap persepsi pengusaha terkait pentingnya pembukuan dan pelaporan keuangan bagi usahanya.

Berdasarkan penjelasan di atas, maka hipotesis yang dapat diajukan adalah:

\section{H4 : Ukuran Usaha berpengaruh positif terhadap penerapan SAK ETAP pada UMKM}

\section{METODE PENELITIAN}

\section{Populasi dan Sampel}

Populasi dalam penelitian ini adalah seluruh UMKM di Indonesia. Untuk membatasi jumlah UMKM, penelitian ini hanya meneliti UMKM yang berada di Kota Tegal.

Untuk menentukan banyaknya sampel (ukuran sampel) dari suatu populasi dapat dihitung dengan rumus slovin sebagai berikut Wahyuningsih (2013):

$$
\begin{aligned}
& \mathbf{n}=\frac{N}{1+N(e)^{2}} \\
& \mathbf{n}=\frac{771}{1+771(0,1)^{2}} \\
& \mathbf{n}=\mathbf{6 4}
\end{aligned}
$$

Keterangan :

$\mathrm{n}=$ ukuran sampel

$\mathrm{N}=$ ukuran populasi

$\mathrm{e}=$ persen kelonggaran ketidaktelitian karena kesalahan pengambilan sampel yang masih dapat ditolerir atau diinginkan, umumnya $10 \%$.

Metode Pengumpulan Data

Pengumpulan data akan dilakukan melalui tehnik wawancara dan kuesioner yang kepada pemilik Usaha Mikro Kecil dan Menengah yang ada di Sekitar Kota Tegal.

1. Wawancara

Metode pengumpulan data dengan cara wawancara langsung dengan pihak-pihak tertentu dan dikerjakan dengan sistematis berdasarkan tujuan penelitian.

2. Kuesioner

Yaitu proses pengumpulan data melalui daftar pertanyaan yang disusun secara sistematis dan bersifat tertutup artinya responden memberikan jawaban berdasarkan pilihan jawaban yang telah disediakan Indriyantoro dan Bambang (1999).

\section{Metode Analisis Data}

metode analisis data pada penelitian ini menggunakan regresi linier berganda. Dimana terdiri dari uji asumsi klasik, model persamaannya terdiri atas 1. Uji Normalitas dengan one sample kolmogorov smirnov 2. Uji Multikolinearitas dengan VIF 3. Uji Heteroskedastisitas dengan melihat grafik scatterplot.

Jurnal Akuntansi Indonesia 


\section{HASIL DAN PEMBAHASAN}

\section{Deskripsi Sampel}

Sampel penelitian ini adalah UMKM di Kota Tegal. Kuesioner didistribusikan kepada pemilik Usaha Mikro Kecil dan Menengah UMKM yang ada di Kota Tegal. Dari 64 kuesioner yang didistribusikan pada bulan September 2014, tidak semuanya dapat digunakan untuk analisis dimana 15 kuesioner tidak kembali dan 8 jawaban tidak lengkap. Dengan demikian ternyata hanya 41 kuesioner saja yang digunakan untuk analisis dan pengolahan data. Agar lebih jelasnya dapat melihat tabel 1.

\section{Definisi Operasional dan Pengukuran Variabel}

Ada dua variabel dalam penelitian ini, yaitu:

1. Variabel Independen

Variabel independen dalam penelitian ini adalah:

a. Pendidikan pemilik

b. Pemahaman teknologi informasi

c. Karakteristik kualitatif laporan keuangan

d. Ukuran Usaha UMKM

2. Variabel Dependen

Variabel dependen dalam penelitian ini adalah penerapan SAK ETAP bagi UMKM.

Untuk lebih jelasnya dapat dilihat pada Tabel 2.

\section{Deskripsi Variabel}

Diskripsi variabel disini dimaksudkan untuk menganalisis data berdasarkan atas hasil yang diperoleh dari jawaban responden terhadap masing-masing indikator pengukur variabel, dapat dilihat pada tabel 2. Berdasarkan data tersebut menunjukkan bahwa variabel Pendidikan Pemilik menunjukkan rata-rata empiris sebesar 15.07 yang berada di atas rata-rata teoritisnya yaitu 12. Hal ini menunjukkan subyek penelitian secara umum mendapatkan bahwa pendidikan pemilik berada di atas rata-rata. Jika dikategorikan dalam 5 kelompok, rata-rata empiris pendidikan pemilik sebesar 15.07 tersebut berada pada kategori Sedang. Hal ini menunjukkan bahwa secara umum kelompok sampel memiliki pendidikan yang sedang yakni SMA .

Variabel Pemahaman Tehnologi Informasi menunjukkan rata-rata empiris sebesar 7.51 yang berada di atas bawah teoritisnya yaitu 6. Hal ini menunjukkan subyek penelitian secara umum mendapatkan bahwa pemahaman mengenai Teknologi informasi dari sampel masih relatif kurang. Jika diktegorikan dalam 5 kelompok, rata-rata empiris variabel Pemahaman Tehnologi Informasi sebesar 7.51 tersebut berada pada kategori Sedang.

Variabel Karakteristik Kualitatif Laporan Keuangan menunjukkan rata-rata empiris sebesar 19.00 yang berada di atas rata-rata teoritisnya yaitu $15 \mathrm{Hal}$ ini menunjukkan subyek penelitian secara umum mendapatkan bahwa UMKM sampel sudah memiliki karakteristik kualitatif laporan keuangan yang lebih tinggi dari nilai tengah ukuran skalanya. Jika dikelompokkan dalam kategori 5 kelompok, maka rata-rata empiris karakteristik 
laporan keuangan sebesar 19.00 tersebut berada pada kategori Tinggi.

Variabel Ukuran usaha menunjukkan rata-rata empiris sebesar 4.15 yang berada di bawah rata-rata teoritisnya yaitu 6.00. Hal ini menunjukkan subyek penelitian secara umum memiliki ukuran usaha yang relatif kecil. Jika dikelompokkan dalam kategori 5 kelompok, maka rata-rata empiris skor Ukuran usaha sebesar 4.15 tersebut berada pada kategori Rendah.

Variabel Penerapan SAK ETAP menunjukkan rata-rata empiris sebesar 4.68 yang berada di bawah rata-rata teoritisnya yaitu 6. Hal ini menunjukkan subyek penelitian secara umum subyek masih memiliki penerapan SAK ETAP yang lebih kecil dari rata-rata. Jika dikelompokkan dalam kategori 5 kelompok, maka rata-rata empiris skor penerapan SAK ETAP sebesar 4.68 tersebut berada pada kategori Sedang.

\section{Analisis Data}

Sebelum membahas pada pembuktian dan pembahasan hasil penelitian, untuk menghindari bisa penelitian yang muncul dari pengumpulan data kuesioner, terlebih dahulu akan dibahas dan ditunjukkan mengenai diskripsi jawaban responden, validitas dan reliabilitas dari item-item kuesioner yang digunakan dalam penelitian ini.

\section{Uji Validitas dan Reliabilitas}

Uji validitas digunakan untuk menguji keabsahan dari kuesioner yang digunakan untuk mengukur suatu variabel. Pengujian validitas dilakukan dengan menggunakan rumus korelasi. Sebuah indikator dinyatakan valid jika memiliki nilai korelasi diatas $r$ tabel. Dari tabel 4 dapat diperoleh bahwa semua indikator yang digunakan untuk mengukur variabel-variabel yang digunakan dalam penelitian ini mempunyai koefisien

korelasi yang lebih besar dari $r_{\text {table }}=0.308$ (nilai $r$ tabel untuk $n=41$ ). Sehingga semua indikator tersebut adalah valid.

Uji reliabilitas dilakukan untuk mengetahui kehandalan dari suatu alat ukur (kuesoioner) dalam mengukur suatu variabel. Pengujian reliabilitas akan dilakukan dengan menggunakan Cronbach Alpha. Ringkasan hasil pengujian Reliabilitas selengkapnya dapat dilihat pada Tabel 5. Dari hasil tersebut menunjukkan bahwa semua variabel mempunyai koefisien Alpha yang cukup besar yaitu diatas 0.60 sehingga dapat dikatakan semua konsep pengukur masing-masing variabel dari kuesioner adalah reliabel sehingga untuk selanjutnya itemitem pada masing-masing konsep variabel tersebut layak digunakan sebagai alat ukur.

\section{Analisis Regresi Linier Berganda}

Hasil pengujian pengaruh asumsi klasik dapat disajikan pada sebagai berikut.

1. Uji Normalitas

Pengujian asumsi normalitas dilakukan untuk variabel secara individual dan juga pengujian untuk model regresi. Pengujian akan dilakukan dengan menggunakan PP Plot. Hasil pengujian normalitas secara dapat dilihat pada gambar 2 dan tabel 6. Hasil pengujian tersebut menunjukkan residual (kesalahan pengganggu) yang berdistribusi normal karena hasil uji PP Plot menunjukkan nilai residual yang dekat 
dengan garis diagonal. Hasil uji dengan Kolmogorov Smirnov menunjukkan signifikansi sebesar $0.884>$ 0.05 yang mendukung data yang berdistribusi normal.

2. Uji Multikolinearitas

Pengujian multikolinearitas dilakukan dengan menggunakan nilai VIF. Pengujian multikolinieritas dilakukan pada model regresi. Hasil pengujian diperoleh pada Tabel 7. Dari hasil tersebut menunjukkan bahwa semua variabel bebas mempunyai nilai VIF yang berada jauh di bawah angka 10 sehingga dapat dikatakan semua konsep pengukur variabel-variabel yang digunakan tidak mengandung masalah multikolinieritas.

3. Uji Heteroskedastisitas

Pengujian heteroskedastisitas dilakukan dengan menggunakan uji Scatter Plot. Jika terdapat hasil pola yang menyebar, maka disimpulkan bahwa model regresi tidak mengandung adanya gejala heteroskedastisitas, dapat dilihat pada gambar 3 dan tabel 8. Hasil pengujian heteroskedastisitas menunjukkan bahwa tidak terdapat pola yang menunjukkan adanya hubungan yang signifikan antara predictor dengan nilai residualnya. Hal ini berarti bahwa model regresi tidak memiliki gejala adanya heteroskedastisitas.

\section{Model Regresi}

Perhitungan statistik dalam analisis regresi linier berganda yang digunakan dalam penelitian ini adalah dengan menggunakan bantuan program komputer SPSS for Windows versi 16.0. dapat dilihat pada gambar 9. Model persamaan regresi yang dapat dituliskan dari hasil tersebut dalam bentuk persamaan regresi bentuk standard adalah sebagai berikut :

$$
Y=-4,790+0,179 X_{1}+0,286 X_{2}+0,209 X_{3}+0,155 X_{4}+e
$$

Koefisien regresi pada semua variabel bebas diperoleh memiliki tanda koefisien positif yang sesuai dengan yang diharapkan. Namun demikian pengujian hipotesis akan diuji selanjutnya dengan pengujian statistik dengan tingkat kepercayaan 95\% atau dengan e $=5 \%$. Hasil persamaan regresi linier berganda tersebut memberikan pengertian bahwa :

a. Nilai konstanta bernilai negatif, artinya apabila pendidikan pemilik, pemahaman teknologi informasi, karakteristik kualitatif laporan keuangan dan ukuran usaha UMKM konstan maka penerapan SAK ETAP bagi UMKM adalah negatif.

b. b1 (nilai koefisien regresi pendidikan pemilik) bernilai positif, mempunyai arti apabila pendidikan pemilik semakin meningkat, maka penerapan SAK ETAP pada UMKM semakin meningkat.

c. b2 (nilai koefisien regresi pemahaman teknologi informasi) bernilai positif. Mempunyai arti apabila pemahaman teknologi semakin meningkat, maka penerapan SAK ETAP UMKM semakin meningkat.

d. b3 (nilai koefisien regresi karakteristik kualitatif laporan keuangan) bernilai positif. Mempunyai arti apabila karakteristik kualitatif laporan keuangan semakin meningkat, maka penerapan SAK ETAP pada UMKM semakin meningkat.

e. b4 (nilai ukuran usaha UMKM) bernilai positif, mempunyai arti apabila Ukuran Usaha UMKM semakin 
meningkat, maka penerapan SAK ETAP pada UMKM semakin meningkat.

\section{Uji Model}

Untuk menguji model regresi pengaruh variabel bebas secara bersama-sama diuji dengan menggunakan uji F. Hasil perhitungan regresi dapat dilihat pada tabel 10. Pengujian pengaruh variabel bebas secara bersama-sama terhadap variabel terikatnya dilakukan dengan menggunakan uji F. Hasil perhitungan statistik menunjukkan nilai $F$ hitung $=17.230$ dengan signifikansi sebesar 0.000 . Dengan menggunakan batas signifikansi 0.05, maka diperoleh nilai signifikansi tersebut lebih kecil dari 0.05. Hal ini berarti bahwa pendidikan pemilik. Pemahaman tehnologi informasi, karakteristik kualitatif laporan keuangan dan ukuran usaha UMKM memiliki pengaruh yang signifikan terhadap Penerapan SAK ETAP.

\section{Koefisien Determinasi}

Koefisien determinasi (adjusted $\mathrm{R}^{2}$ ) untuk mengukur seberapa besar kemampuan variabel bebas dalam menerangkan variabel terikat, dapat dilihat pada tabel 11. Hasil perhitungan regresi dapat diketahui bahwa koefisien determinasi (adjusted $R^{2}$ ) yang diperoleh sebesar 0.619. Hal ini berarti 61.9\% Penerapan Kebutuhan SAK ETAP dipengaruhi oleh variabel bebas pendidikan pemilik, pemahaman Tehnologi Informasi dan karakteristik Kualitatif Laporan Keuangan, dan ukuran usaha UMKM sedangkan 38.1\% dipengaruhi oleh variable lain yang tidak diamati.

\section{PEMBAHASAN}

\section{Pengaruh pendidikan pemilik terhadapan Penerapan SAK ETAP pada UMKM}

Pengaruh pendidikan pemilik terhadap Penerapan SAK ETAP menunjukkan arah positif dan signifikan. Kondisi demikian menunjukkan bahwa seorang pemilik UMKM yang mempunyai pendidikan yang tinggi cenderung menginginkan untuk dapat menggunakan SAK ETAP yang lebih baik. Kemampuan dan keahlian manajer atau pemilik UMKM saat ini sangat ditentukan dari pendidikan formal yang pernah ditempuh. Tingkat pendidikan formal yang rendah ( Sekolah Dasar dan Sekolah Menengah Pertama ) manajer atau pemilik maka akan rendah pula penyiapan dan penggunaan informasi akuntansi dibandingkan dengan tingkat pendidikan formal yang tinggi (SMA, Sarjana dan sederajat). Hasil penelitian ini sesuai dengan penelitian Murniati (2002); Aufar (2013); Sariningtyas dan Diah (2011).

\section{Pengaruh pemahaman Tehnologi Informasi terhadap Penerapan SAK ETAP pada UMKM}

Pengaruh pemahaman Tehnologi Informasi oleh pemilik UMKM terhadap Penerapan SAK ETAP menunjukkan arah positif dan signifikan. Kondisi demikian menunjukkan bahwa seorang pemilik UMKM yang mempunyai pemahaman mengenai Tehnologi Informasi yang lebih baik cenderung menginkan untuk dapat menggunakan SAK ETAP yang lebih baik. Hal ini sesuai dengan penelitian Rudiantoro dan Siregar ( 2011); Suhairi (2004); Pinasti (2007). 


\section{Pengaruh karakteristik kualitatif Laporan keuangan terhadap Penerapan SAK ETAP pada UMKM}

Pengaruh karakteristik kualitatif laporan keuangan UMKM terhadap rendahnya Penerapan SAK ETAP menunjukkan arah positif dan signifikan. Kondisi demikian menunjukkan bahwa UMKM yang mempunyai karakteristik kualifikasi laporan keuangan yang lebih rumit yang tentunya memerlukan penerapan prosedur yang lebih baik.

Penerapan SAK ETAP akan lebih terasa manfaatnya manakala karakteristik kualitatif laporan keuangan yang harus dibuat oleh UMKM lebih lengkap dan memenuhi prosedur akuntansi yang benar. Dengan demikian maka pemanfaatan SAK ETAP akan semakin dibutuhkan untuk menyesuaikan dengan kondisi yang diharapkan oleh perusahaan. Hal ini sesuai dengan penelitian Rudiantoro dan Siregar (2011); Sariningtyas dan Diah (2011); Sarifah (2012).

\section{Pengaruh Ukuran Usaha UMKM terhadap Penerapan SAK ETAP pada UMKM}

Pengaruh ukuran usaha UMKM terhadap Penerapan SAKETAP menunjukkan arah positif. Kondisi demikian menunjukkan bahwa ukuran usaha UMKM akan menjadikan ketertarikan yang lebih besar bagi UMKM untuk menerapkan SAK ETAP.

Ukuran usaha UMKM merupakan salah satu bentuk peningkatan pengalaman usaha yang dilakukan oleh UMKM tersebut. UMKM yang sudah berdiri lama akan memungkinkan memiliki pengalaman yang lebih banyak mengenai hambatan dan kendala yang dihadapi dalam proses akuntansinya. Selain itu UMKM yan sudah lama berdiri umumnya sudah mendapatkan pelatihan dalam penerapan akuntansi. Dengan demikian ukuran usaha menjadi salah satu sasaran dan tujuan sosialisai SAKETAP. Semakin besarnya ukuran usaha UMKM akan menjadikan penerapan SAK ETAP semakin dibutuhkan. Hal ini sesuai dengan penelitian Rudiantoro dan Siregar (2011); Aufar (2013); Sarifah (2012).

\section{SIMPULAN}

Dari hasil analisis data dapat diperoleh kesimpulan sebagai berikut.

1. Hasil pengujian mendapatkan bahwa pendidikan pemilik memiliki pengaruh terhadap penerapan SAK ETAP. Semakin tinggi tingkat pendidikan pemilik UMKM maka semakin tinggi juga pengetahuan akan akuntansinya tentang penerapan SAK ETAP.

2. Hasil pengujian mendapatkan bahwa pemahaman Tehnologi Informasi memiliki pengaruh terhadap penerapan SAK ETAP. Semakin tinggi tingkat pemahaman teknologi informasi pada pemilik UMKM akan meningkatkan penerapan SAK ETAP.

3. Hasil pengujian mendapatkan bahwa kerakteristik kualitatif laporan keuangan UMKM memiliki pengaruh terhadap penerapan SAK ETAP. Semakin lengkap karakteristik kualifikasi laporan keuangan UMKM maka penerapan SAK ETAP pada UMKM akan baik.

4. Hasil pengujian mendapatkan bahwa ukuran usaha UMKM memiliki pengaruh terhadap penerapan SAK ETAP. Semakin lama usaha UMKM berdiri maka penerapan SAK ETAP pada UMKM akan meningkat. 


\section{Saran Penelitian}

Saran-saran yang dapat diberikan sebagai tindak lanjut dari hasil penelitian adalah sebagai berikut :

1. Perlunya sosialisasi mengenai penggunaan standar akuntansi yang benar nampaknya sangat diperlukan dan diberikan kepada pemilik UMKM.

2. Pengenalan teknologi informasi nampaknya juga semakin diperlukan bagi para pemilik UMKM.

3. Untuk penelitian selanjutnya diharapkan untuk meneliti lebih banyak variabel dan sampel.

\section{Keterbatasan Penelitian}

Keterbatasan dalam penelitian ini adalah :

1. Penelitian ini menggunakan hanya 1 lokasi yaitu UMKM Kota Tegal. Kondisi ini dapat diartikan bahwa hasil penelitian ini belum bisa digeneralisasikan bagi penelitian dengan lokasi yang sama.

2. Masih rendahnya pengetahuan serta pemahaman para pengusaha terkait SAK ETAP, karena SAK ETAP merupakan standar akuntansi yang wajib digunakan oleh UMKM.

3. Kendala yang bersifat situasional, yaitu berupa situasi yang dirasakan responden pada saat pengisian kuesioner tersebut akan dapat mempengaruhi cara menjawab.

\section{DAFTAR PUSTAKA}

Aufar, A,. 2013. Faktor - Faktor Yang Mempengaruhi Penggunaan Informasi Akuntansi Pada UMKM (Usaha Mikro, Kecil, dan Menengah) (Survei Pada Perusahaan Rekanan PT. PLN (Persero) Kota Bandung.

Auliyah, M. I. 2012. Penerapan Akuntansi berdasarkan Standar Akuntansi Keuangan pada UKM Kampung Batik di Sidoarjo. Artikel IImiah. STIE Perbanas. Surabaya.

Ferly, P,. 2013. Peran Akuntansi Dalam Pemberdayaan. Melalui<http://www.ferly progresif.blogspot.com/2013/ peran-akuntansi-dalam-pemberdayaan. html[2/2/2014].

Indriantoro, N., dan S. Bambang. 1999. Metodologi Penelitian Bisnis. Edisi Pertama. Yogyakarta: BPFE.

Murniati. 2002. Analisis Faktor - Faktor yang Mempengaruhi Penyiapan dan Penggunaan Informasi Akuntansi pada Pengusaha Kecil dan Menengah di Jawa Tengah.

Pinasti, M. 2007. Pengaruh Penyelenggaraan dan Penggunaan Informasi Akuntansi terhadap Persepsi pengusaha kecil dan Informasi Akuntansi Suatu Riset Eksperimen.

Rudiantoro, R., dan S. S.Veronica. 2011. Kualitas Laporan Keuangan UMKM Serta Prospek Implementasi SAK ETAP. Simposium Nasional Akuntansi XIV Aceh.

Sarifah, H. 2012. Analisis Persepsi SAK ETAP Pada UMKM Se-Kota Semarang. Simposium Accounting Analysis JURnal UNNES.

Sariningtyas, P., dan T. W. Diah. 2011. Standar Akuntansi Keuangan Entitas Tanpa Akuntabilitas Publik Pada Usaha Kecil dan Menengah. Jurnal Akuntansi, Vol. 1 No. 1:90-101.

Suhairi. 2004. Personality, Accounting Knowledge Accounting Information Usage and Performance; A Research On Entrepreneurship Of Indonesia Medium Industries. Disertasi. USM Malaysia.

Wahdini dan Suhairi. 2006. Persepsi Akuntan Terhadap Overload Standar Akuntansi Keuangan (SAK ETAP) Bagi 
Usaha Kecil dan Menengah. Simposium Nasional Akuntansi IX Padang

Wahyuningsih, N. 2013. Faktor - Faktor Yang Mempengaruhi Kebutuhan Standar Akuntansi Keuangan Entitas

Tanpa Akuntabilitas Publik (SAK ETAP) Bagi Usaha Kecil Dan Menengah (UKM). Skripsi. FakultasEkonomi UNISSULA. Semarang. 


\section{LAMPIRAN}

Tabel 1

Sampel Penelitian

\begin{tabular}{ll}
\hline \multicolumn{1}{c}{ Keterangan } & Jumlah \\
\hline Jumlah kuesioner yang didistribusikan & 64 \\
\hline Jumlah kuesioner yang tidak kembali & 15 \\
\hline & \multicolumn{2}{c}{49} \\
\hline Kuesioner dengan jawaban tidak lengkap & $(8)$ \\
\hline Kuesioner yang dapat diolah & 41 \\
\hline
\end{tabular}

Tabel 2

Definisi Operasional dan Pengukuran Variabel

\begin{tabular}{|c|c|c|c|}
\hline Variabel & Definisi Operasional & Indikator & Pengukur \\
\hline Pendidikan Pemilik & $\begin{array}{l}\text { Proses pembelajaran untuk } \\
\text { meningkatkan pengetahuan yang } \\
\text { diperoleh melalui pendidikan } \\
\text { formal dan non formal. } \\
\text { Sariningtyas dan Diah (2011) }\end{array}$ & $\begin{array}{l}\text { 1. Pendidikan } \\
\text { Formal } \\
\text { 2. Pendidikan } \\
\text { Nonformal } \\
\text { 3. Pengetahuan } \\
\text { Formal } \\
\text { 4. Pengetahuan } \\
\text { Nonformal } \\
\end{array}$ & $\begin{array}{l}\text { Skala likert: } \\
\text { 1. Sangat Tidak } \\
\text { Setuju } \\
\text { 2. Tidak Setuju } \\
\text { 3. Netral } \\
\text { 4. Setuju } \\
\text { 5. Sangat Setuju }\end{array}$ \\
\hline $\begin{array}{l}\text { Pemahaman } \\
\text { Teknologi } \\
\text { Informasi }\end{array}$ & $\begin{array}{l}\text { Mampu dalam memahami } \\
\text { informasi yang dihasilkan dari } \\
\text { berbagai bidang, seperti di } \\
\text { bidang teknologi ataupun bidang } \\
\text { pengetahuan Sariningtyas dan } \\
\text { Diah 2011). }\end{array}$ & $\begin{array}{l}\text { 1. Pemahaman } \\
\text { Tehnologi } \\
\text { Informasi } \\
\text { 2. Keterampilan } \\
\text { Tehnologi } \\
\text { Informasi }\end{array}$ & $\begin{array}{l}\text { Skala likert: } \\
\text { 1. Sangat Tidak } \\
\text { 2. Setuju } \\
\text { 3. Tidak Setuju } \\
\text { 4. Netral } \\
\text { 5. Setuju } \\
\text { 6. Sangat Setuju }\end{array}$ \\
\hline $\begin{array}{l}\text { Karakteristik } \\
\text { Kualitatif } \\
\text { Laporan } \\
\text { Keuangan }\end{array}$ & $\begin{array}{l}\text { Informasi yang menyangkut posisi } \\
\text { keuangan, kinerja } \\
\text { serta perubahan posisi keuangan } \\
\text { suatu perusahaan yang } \\
\text { bermanfaat bagi sejumlah besar } \\
\text { pamakai dalam pengambilan } \\
\text { keputusan ekonomi Sariningtyas } \\
\text { dan Diah (2011). }\end{array}$ & $\begin{array}{l}\text { 1. Sederhana } \\
\text { dan dapat } \\
\text { dipahami } \\
\text { 2. Tepat waktu } \\
\text { 3. Dapat dipercaya } \\
\text { 4. Jujur } \\
\text { 5. Dapat } \\
\text { dibandingkan }\end{array}$ & 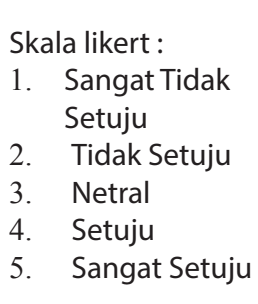 \\
\hline
\end{tabular}

Ukuran usaha merupakan faktor yang sulit dipisahkan dengan lingkungan pengusaha UMKM. Ukuran usaha dapat mempengaruhi pemikiran pengusaha terkait dengan Ukuran Usaha kompleksitas dan semakin UMKM tingginya tingkat transaksi perusahaan sehingga diharapkan dengan makin besarnya ukuran usaha maka dapat mendorong sesorang untuk berpikir dan belajar terkait solusi untuk menghadapinya. Pinasti (2011)

Skala likert :

1. Lama Usaha 1. SangatTidak UMKM Setuju

2. Banyaknya 2. Tidak Setuju Transaksi Usaha 3. Netral UMKM 4. Setuju

5. Sangat Setuju 


\begin{tabular}{llll}
\hline & Walaupun dengan adanya SAK & & \\
& ETAP untuk mempermudah & & \\
& UMKM dalam melakukan & 1. Pemahaman SAK & Skala likert: \\
& pencatatan keuangan & ETAP bagi UMKM & 1. Sangat Tidak \\
Penerapan SAK & untuk usahanya, tapi dalam & 2. Proses & 2. Tidak Setuju \\
ETAP Bagi UMKM & implementasinya pencatatan & pencatatan & 3. Netral \\
& keuangan yang dilakukan oleh & laporan & 4. Setuju \\
& UMKM masih jauh dari standar & keuangan UMKM & 5. Sangat Setuju \\
& yang telah ditetapkan Andriani & & \\
\hline
\end{tabular}

Sumber : Dikembangkan untuk penelitian ini.

Tabel 3. Deskripsi Variabel

\begin{tabular}{|c|c|c|c|c|c|}
\hline Variabel & Item & Ukuran & Teoritis & Empiris & Ket \\
\hline Pendidikan pemilik & 4 & $\begin{array}{l}\text { Minimum } \\
\text { Maksimum } \\
\text { Mean } \\
\text { Sangat Rendah } \\
\text { Rendah } \\
\text { Sedang } \\
\text { Tinggi } \\
\text { Sangat Tinggi }\end{array}$ & $\begin{array}{l}4 \\
20 \\
12 \\
9.00-11.20 \\
11.21-13.41 \\
13.42-15.62 \\
15.63-17.83 \\
17.84-20.04\end{array}$ & $\begin{array}{l}9 \\
20 \\
15.07\end{array}$ & Sedang \\
\hline $\begin{array}{l}\text { Pemahaman } \\
\text { Tehnologi } \\
\text { Informasi }\end{array}$ & 2 & $\begin{array}{l}\text { Minimum } \\
\text { Maksimum } \\
\text { Mean } \\
\text { Sangat Rendah } \\
\text { Rendah } \\
\text { Sedang } \\
\text { Tinggi } \\
\text { Sangat Tinggi }\end{array}$ & $\begin{array}{l}2 \\
10 \\
6 \\
4.00-5.20 \\
5.21-6.41 \\
6.42-7.62 \\
7.63-8.83 \\
8.84-10.04\end{array}$ & $\begin{array}{l}4 \\
10 \\
7.51\end{array}$ & Sedang \\
\hline $\begin{array}{l}\text { Karakteristik } \\
\text { Kualitatif Laporan } \\
\text { Keuangan }\end{array}$ & 5 & $\begin{array}{l}\text { Minimum } \\
\text { Maksimum } \\
\text { Mean } \\
\text { Sangat Rendah } \\
\text { Rendah } \\
\text { Sedang } \\
\text { Tinggi } \\
\text { Sangat Tinggi }\end{array}$ & $\begin{array}{l}5 \\
25 \\
15 \\
14.00-15.60 \\
15.61-17.21 \\
17.22-18.82 \\
18.83-20.43 \\
20.44-22.04\end{array}$ & $\begin{array}{l}14 \\
22 \\
19.00\end{array}$ & Tinggi \\
\hline Ukuran Usaha & 2 & $\begin{array}{l}\text { Minimum } \\
\text { Maksimum } \\
\text { Mean } \\
\text { Sangat Rendah } \\
\text { Rendah } \\
\text { Sedang } \\
\text { Tinggi } \\
\text { Sangat Tinggi }\end{array}$ & $\begin{array}{l}2 \\
10 \\
6 \\
2.00-3.60 \\
3.61-5.21 \\
5.22-6.82 \\
6.83-8.43 \\
8.44-10.04\end{array}$ & $\begin{array}{l}2 \\
10 \\
4.15\end{array}$ & Rendah \\
\hline
\end{tabular}


JURNAL AKUNTANSI INDONESIA

\begin{tabular}{lllll}
\hline & Minimum & 2 & & \\
& Maksimum & 10 & 2 & \\
& Mean & 6 & 7 & Sedang \\
Penerapan SAK & Sangat Rendah & $2.00-3.00$ & 4.68 & \\
ETAP & 2 & Rendah & $3.01-4.01$ & \\
& Sedang & $4.02-5.02$ & & \\
& Tinggi & $5.03-6.03$ & & \\
& Sangat Tinggi & $6.04-7.04$ & & \\
& & & \\
\end{tabular}

Tabel 4

Pengujian Validitas \& Hasil Pengujian Validitas

\begin{tabular}{|c|c|c|c|}
\hline Variabel / Indikator & Korelasi & R table & Keterangan \\
\hline \multicolumn{4}{|l|}{ Pendidikan Pemilik } \\
\hline $\mathrm{X} 1.1$ & 0.503 & 0.308 & Valid \\
\hline $\mathrm{X} 1.2$ & 0.779 & 0.308 & Valid \\
\hline $\mathrm{X} 1.3$ & 0.804 & 0.308 & Valid \\
\hline $\mathrm{X} 1.4$ & 0.827 & 0.308 & Valid \\
\hline \multicolumn{4}{|c|}{ Pemahaman Tehnologi Informasi } \\
\hline $\mathrm{X} 2.1$ & 0.863 & 0.308 & Valid \\
\hline $\mathrm{X} 2.2$ & 0.888 & 0.308 & Valid \\
\hline \multicolumn{4}{|c|}{ Karakteristik Kualitatif Laporan Keuangan } \\
\hline $\mathrm{X} 3.1$ & 0.723 & 0.308 & Valid \\
\hline $\mathrm{X} 3.2$ & 0.756 & 0.308 & Valid \\
\hline $\mathrm{X} 3.3$ & 0.655 & 0.308 & Valid \\
\hline X3.4 & 0.692 & 0.308 & Valid \\
\hline $\mathrm{X} 3.5$ & 0.730 & 0.308 & Valid \\
\hline \multicolumn{4}{|l|}{ Ukuran Usaha } \\
\hline $\mathrm{X} 4.1$ & 0.989 & 0.308 & Valid \\
\hline$X 4.2$ & 0.991 & 0.308 & Valid \\
\hline \multicolumn{4}{|l|}{ Penerapan SAK ETAP } \\
\hline y.1 & 0.923 & 0.308 & Valid \\
\hline y.2 & 0.867 & 0.308 & Valid \\
\hline
\end{tabular}

Tabel 5. Pengujian Reliabilitas

\begin{tabular}{lll}
\hline \multicolumn{1}{c}{ Variabel } & Alpha & Keterangan \\
\hline Pendidikan pemilik & 0.719 & Reliabel \\
\hline Pemahaman Tehnologi Informasi & 0.694 & Reliabel \\
\hline Karakteristik Kualitatif Laporan Keuangan & 0.754 & Reliabel \\
\hline Ukuran Usaha & 0.978 & Reliabel \\
\hline Penerapan SAK ETAP & 0.741 & Reliabel \\
\hline
\end{tabular}

Sumber : Data primer yang diolah, 2014 


\section{Tabel 6}

One-Sample Kolmogorov-Smirnov Test

\begin{tabular}{llr}
\hline & & $\begin{array}{r}\text { Unstandardized } \\
\text { Residual }\end{array}$ \\
\hline $\mathrm{N}$ & & 41 \\
\hline \multirow{2}{*}{ Normal Parameters } & & .0000000 \\
\hline \multirow{2}{*}{ Most Extreme Differences } & Std. Deviation & .86326635 \\
\cline { 2 - 3 } & Absolute & .091 \\
\cline { 2 - 3 } & Positive & .091 \\
\cline { 2 - 3 } & Negative &. .080 \\
\hline Kolmogorov-Smirnov Z & & .585 \\
\hline Asymp. Sig. (2-tailed) & & .884 \\
\hline a. Test distribution is Normal. & & \\
\hline
\end{tabular}

Tabel 7

Pengujian Multikolinieritas

\begin{tabular}{clcc}
\hline \multirow{2}{*}{ Model } & \multicolumn{3}{c}{ Collinearity Statistics } \\
\cline { 2 - 4 } & Pondidikan pemilik & .707 & 1.414 \\
\cline { 2 - 4 } & $\begin{array}{l}\text { Pemahaman Tehnologi } \\
\text { Informasi }\end{array}$ & .670 & 1.493 \\
\cline { 2 - 4 } $\begin{array}{l}\text { Karakteristik Kualitatif Laporan } \\
\text { Keuangan }\end{array}$ & .625 & 1.600 \\
\cline { 2 - 4 } & Ukuran Usaha & .950 & 1.053 \\
\hline
\end{tabular}

Tabel 8.

Uji Heterokedastitas

\begin{tabular}{|c|c|c|c|c|}
\hline \multicolumn{5}{|c|}{ Coefficients $^{\mathrm{a}}$} \\
\hline $\begin{array}{r}\text { Unstanc } \\
\text { Coeffi }\end{array}$ & $\begin{array}{l}\text { ardized } \\
\text { ients }\end{array}$ & $\begin{array}{c}\text { Standardized } \\
\text { Coefficients }\end{array}$ & $t$ & Sig. \\
\hline$B$ & Std. Error & Beta & & \\
\hline 1.462 & .767 & & 1.906 & .065 \\
\hline-.052 & .042 & -.230 & -1.245 & .221 \\
\hline-.080 & .059 & -.259 & -1.368 & .180 \\
\hline .036 & .049 & .146 & .747 & .460 \\
\hline-.023 & .033 & -.111 & -.700 & .488 \\
\hline
\end{tabular}

a. Dependent Variable: AbsRes 
Tabel 9

Analisis regresi linier berganda

\begin{tabular}{|c|c|c|c|c|c|c|}
\hline \multirow[t]{2}{*}{ Model } & & \multicolumn{2}{|c|}{ Unstandardized Coefficients } & \multirow{2}{*}{$\begin{array}{c}\text { Standardized } \\
\text { Coefficients } \\
\text { Beta } \\
\end{array}$} & \multirow[t]{2}{*}{$\mathrm{t}$} & \multirow[t]{2}{*}{ Sig. } \\
\hline & & $\mathrm{B}$ & Std. Error & & & \\
\hline \multirow{5}{*}{1} & (Constant) & -4.790 & 1.351 & & -3.545 & .001 \\
\hline & Pendidikan pemilik & .179 & .073 & .284 & 2.450 & .019 \\
\hline & $\begin{array}{l}\text { Pemahaman Tehnologi } \\
\text { Informasi }\end{array}$ & .286 & .103 & .331 & 2.771 & .009 \\
\hline & $\begin{array}{l}\text { Karakteristik Kualitatif } \\
\text { Laporan Keuangan }\end{array}$ & .209 & .086 & .302 & 2.442 & .020 \\
\hline & Ukuran Usaha & .155 & .059 & .265 & 2.646 & .012 \\
\hline
\end{tabular}

a. Dependent Variable: Penerapan SAK ETAP

Tabel 10. Uji Model Regresi

\begin{tabular}{|c|c|c|c|c|c|c|}
\hline \multicolumn{7}{|c|}{ ANOVA $^{\mathrm{b}}$} \\
\hline Model & & Sum of Squares & $\mathrm{df}$ & Mean Square & $\mathrm{F}$ & Sig. \\
\hline \multirow{3}{*}{1} & Regression & 57.069 & 4 & 14.267 & 17.230 & $.000^{\mathrm{a}}$ \\
\hline & Residual & 29.809 & 36 & .828 & & \\
\hline & Total & 86.878 & 40 & & & \\
\hline
\end{tabular}

a. Predictors: (Constant), Ukuran Usaha, Pemahaman Tehnologi Informasi , Pendidikan pemilik, Karakteristik Kualitatif Laporan Keuangan

b. Dependent Variable: Penerapan SAK ETAP

Tabel 11. Koefisien Determinasi

\begin{tabular}{|c|c|c|c|c|c|}
\hline \multicolumn{6}{|c|}{ Model Summary } \\
\hline Model & $\mathrm{R}$ & R Square & Adjusted R Square & $\begin{array}{c}\text { Std. Error of the } \\
\text { Estimate }\end{array}$ & Durbin-Watson \\
\hline 1 & $.810^{\mathrm{a}}$ & .657 & .619 & .90996 & 1.805 \\
\hline
\end{tabular}

Gambar 1. Kerangka Pemikiran 


\section{Gambar 2. Uji Normalitas}

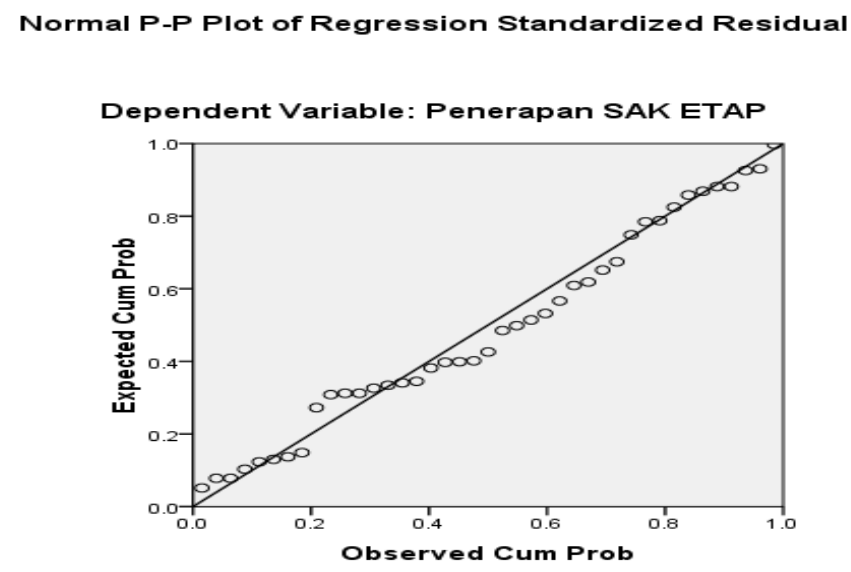

Gambar 3. Uji Heteroskedastitas

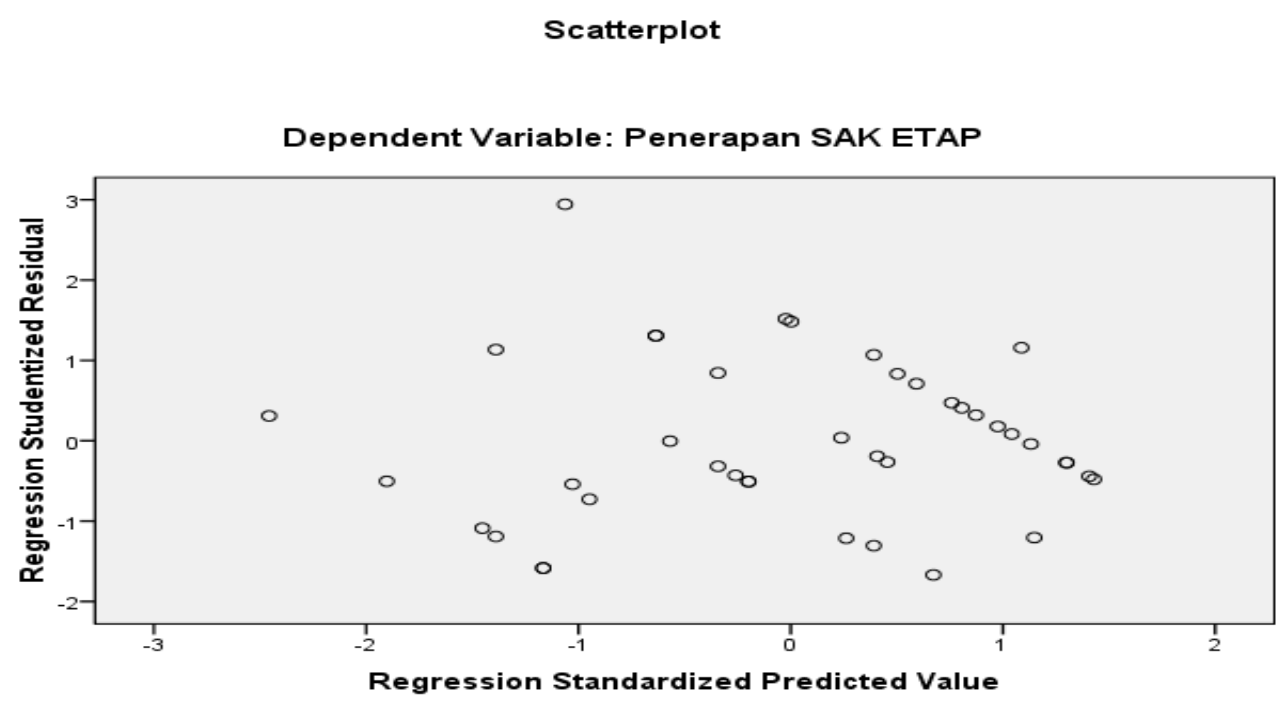


Jurnal Akuntansi Indonesia 